\title{
Contribuições e Dificuldades de Práticas de Leitura e Escrita para Ensinar e Aprender Física no Ensino Médio: Reflexões à Luz da Cultura Escolar
}

\section{Contributions and Difficulties of Reading and Writing Practices for Teaching and Learning Physics in High School: Reflections in Light of School Culture}

\author{
Joselaine Setlik ${ }^{(1)}$ Brasil \\ Ivanilda Higa Brasil
}

Estudos da literatura defendem a importância de práticas de leitura e escrita em aulas de Física, que podem assumir diferentes funções e finalidades na escola. Esta pesquisa analisa perspectivas de diferentes sujeitos, professor e estudantes de um contexto escolar, sobre as contribuições e dificuldades de considerar essas práticas para ensinar e aprender física em aulas da disciplina no Ensino Médio. Compreendendo leitura e escrita como práticas socioculturais e escolarizadas e adotando o conceito de cultura escolar, realizouse o estudo em uma escola pública, em três turmas de terceiro ano. Os instrumentos utilizados foram observações de aulas, intervenção no contexto e entrevistas com 14 estudantes e com o professor, analisando-se as perspectivas desses diferentes sujeitos escolares sobre a temática, à luz do conceito de cultura escolar e da escola. A partir das análises, dentre vários elementos, evidencia-se que nas vozes desses sujeitos, a leitura permite melhor compreensão e ampliação dos olhares sobre os conceitos, enquanto a escrita auxilia na memorização e expressão do conhecimento. A intervenção evidenciou que é possível inserir tais práticas nas aulas de Física, de modo a ampliar as contribuições para o ensino-aprendizagem, explorando outros aspectos relacionados aos conceitos estudados. As dificuldades evidenciadas, por sua vez, referem-se principalmente à relação dos estudantes com essas práticas, à formação docente e a uma cultura escolar que influencia o seu uso, dentro de uma cultura já estabelecida nesta disciplina.

Palavras-chave: Leitura; Escrita; Ensino de Física; Cultura escolar.

Literature reviews defend the importance of reading and writing practices in Physics classes, which can assume different roles and purposes in the school. This research analyzes perspectives of different subjects, teacher and students, about the contributions and difficulties of considering those practices when teaching and learning Physics in classes of this discipline in high school. Assuming reading and writing as sociocultural and schooling practices and adopting the concept of School Culture, the research was carried out in a public school, in three classes of third year of High School. The 
instruments used were classes' observations, intervention, and interviews with 14 students and with the teacher, analyzing the perspectives of these different subjects on such issue, in light of the concept of School Culture and Culture of the School. From the analysis, among several elements, it was observed that for these subjects, reading allows a better understanding and amplification of their perceptions on the concepts, while writing helps memorizing and expressing knowledge. The intervention evidenced that it is possible to adopt such practices in Physics classes, in order to expand the contributions to teaching-learning, by exploring other aspects related to the concepts studied. The difficulties evidenced are mainly associated to the students' relation with these practices, to the teacher training as well as to a school culture that influences their use, especially in a discipline that has its culture already established.

Keywords: Reading; Writing; Physics Teaching; School Culture.

\section{Introdução}

Diferentes disciplinas, em diferentes contextos escolares, podem utilizar a leitura e a escrita com diferentes funções e finalidades. Segundo Guedes e Souza (2011) o desenvolvimento e aperfeiçoamento das práticas de leitura e escrita de textos são responsabilidade de todas as disciplinas escolares, e não apenas da disciplina Língua Portuguesa. As Diretrizes Nacionais da Educação Básica do Ensino Médio, por exemplo, colocam que os projetos político-pedagógicos das escolas devem considerar, entre diversos elementos, "a valorização da leitura e da escrita em todas as áreas do saber" (MEC, 2013, p.178).

Na disciplina Física, no Ensino Médio, pelos menos desde os anos 90 estudos propõem atividades de leitura em sala de aula, defendendo a importância desta prática para a aprendizagem de conceitos e a interação com diferentes áreas de conhecimento (Almeida, \& Ricon, 1993; Almeida, Silva, \& Babichak, 1999; Almeida, Silva, \& Machado, 2001). Como mencionam Almeida e Ricon (1993), a leitura pode, além de facilitar a incorporação do saber científico, contribuir na formação de hábitos e atitudes com relação às informações veiculadas sobre a Ciência.

Os estudos sobre a leitura no ensino de Física defendem que essa prática pode ser potencial para a aprendizagem, desde a leitura de textos de livros didáticos ou paradidáticos (Assis, \& Teixeira, 2005), de divulgação científica (Pagliarini, \& Almeida, 2014; Silva, 2013) a textos de literatura (Ferreira, \& Raboni, 2013).

A relação dos estudantes com o texto escrito pode ocorrer de diferentes formas. Geraldi $^{1}$ (2003, citado por Flôr \& Cassiani, 2011, p. 74) aponta a existência de quatro "tipos" de relações entre texto e leitor: A leitura-busca-de-informações, quando o leitor vai ao texto em busca de respostas a perguntas prévias; a leitura estudo-de-texto, no qual o leitor retira do texto tudo o que ele possa oferecer; a leitura-pretexto, quando o leitor usa o texto na produção de outras obras e a leitura fruição, quando é desfrutado

1 Geraldi, J. W. (2003). Portos de passagem. São Paulo: Martins Fontes. 
da gratuidade da presença do texto. Nas atividades escolares é frequente a utilização da leitura-busca-de-informações, parecendo esta ser uma forma mais limitada de relação entre leitor e texto, já que pode silenciar outras interpretações que possam ser realizadas pelos estudantes.

A escrita em aulas de Física, por sua vez, geralmente vem associada às atividades de leitura. Apesar de em menor número, alguns estudos apontam a potencialidade de diferentes usos da escrita em tal disciplina (Charret, \& Krapas, 2008; Paula, \& Talim, 2015).

Carvalho e Barbeiro (2013) indicam que a escrita pode ser problematizada na escola por diferentes vertentes: como conteúdo escolar a adquirir e desenvolver, portanto a escola sendo responsável por desenvolver as competências do domínio da escrita; como um veículo de comunicação pedagógica, considerando tanto sua dimensão de transmissão dos saberes quanto de explicitação por parte dos alunos, pela avaliação. Os autores mencionam também nova vertente, que é considerar o seu papel no processo de aquisição, elaboração e expressão do conhecimento, concebendo-a como uma ferramenta de aprendizagem. Essa última perspectiva amplia nosso olhar sobre a escrita, pois permite vê-la como potencial na (re)construção do conhecimento pelo estudante nas diversas disciplinas.

Apesar de estudos apontarem potencialidades da leitura e escrita para o ensino-aprendizagem de Física, essas práticas ainda podem causar estranhamentos em professores e alunos que compartilham uma visão de escola na qual determinadas práticas - exercícios e problemas, por exemplo - são mais pertinentes à disciplina, em detrimento da leitura e escrita. Estudos apontam que as práticas de leitura de textos nem sempre são utilizadas/incentivadas (Andrade, \& Martins, 2006; Assis, \& Carvalho, 2008), o que perpassa desde a formação do professor até as condições em que as aulas acontecem. Analisar e entender a presença (ou a invisibilidade) da leitura e da escrita em aulas de Física requer investigar as condições concretas nas quais as aulas de Física ocorrem - em uma escola com professor e alunos imersos em uma determinada cultura (Forquin, 1993) escolar do ensinar e aprender Física.

A pesquisa aqui apresentada busca ampliar os resultados já explicitados em estudos da literatura, refletindo sobre as relações desta temática adotando pressupostos teóricos sobre aprendizagem e linguagem com base em Vigotski e Bakhtin e à luz das discussões de Forquin (1993) sobre a cultura escolar e cultura da escola.

A investigação foi realizada na disciplina Física, em três turmas do terceiro ano do Ensino Médio, a partir de uma caracterização do contexto escolar (mapeando a presença da leitura e da escrita na cultura já estabelecida da disciplina) e do desenvolvimento de uma atividade didática, buscando inserir formas diferenciadas de uso da leitura e da escrita naquela cultura, criando um contexto que permitisse investigar como estudantes e professor se relacionariam (suas respostas individuais) com esta outra forma de abordagem da leitura e escrita nas aulas de Física. 


\section{Os conceitos de cultura escolar e da escola}

A linguagem verbal é essencial no contexto social e na transmissão cultural. A escola faz parte de um contexto social e além da função de transmissão cultural, possui sua própria cultura. Forquin (1993) argumenta que entre educação e cultura existe uma relação íntima e orgânica, distinguindo os conceitos de cultura escolar e cultura da escola, que não devem ser confundidos.

O conceito de cultura escolar está ligado à transmissão cultural de "conteúdos cognitivos e simbólicos que, selecionados, organizados, 'normalizados', 'rotinizados' [...] constituem habitualmente o objeto de uma transmissão deliberada no contexto das escolas" (Forquin, 1993, p. 167). Para esse autor, a cultura escolar é uma cultura seletiva e derivada, que se realiza "pelo entrecruzamento de ações institucionais (currículo oficial), docentes (currículo real) e discentes (currículo aprendido)" (Mendes-Filho, Gonçalves, Vidal, \& Paulilo, 2004, p. 146). A cultura escolar seria assim uma cultura segunda que advém de uma cultura de criação ou invenção, portanto uma cultura derivada e transposta (Mendes-Filho, Gonçalves, Vidal, \& Paulilo, 2004). Julia² (2001, citado em Mendes-Filho, Gonçalves, Vidal, \& Paulilo, 2004, p.143) busca acrescentar, ao excessivo peso das normas dado ao conceito, o olhar sobre as práticas cotidianas, convidando os pesquisadores da área a também se questionarem sobre o funcionamento interno da escola.

As práticas de leitura e escrita podem ser consideradas objetos da cultura, desenvolvidas no meio social (Cruvinel, 2010), e tomadas pela escola nas suas finalidades e meios auxiliares.

A Física, assim como outras disciplinas na Educação Básica, possui características específicas relacionadasà cultura escolar de umainstituição global,ou seja, existem práticas pedagógicas e conteúdos que ao longo da história se constituíram como "pertencentes" à disciplina. Chervel (1990) argumenta que a organização interna das disciplinas é, em certa medida, produto da história. Ao longo da história da constituição das diferentes disciplinas escolares pode ter sido gerado um entendimento de que o desenvolvimento de algumas competências é função de determinadas disciplinas, influenciando as práticas pedagógicas dos professores das escolas. O ensino e desenvolvimento da leitura e da escrita de textos, por exemplo, pode ser majoritariamente incumbido aos professores de língua materna, desprezando-se sua importância na transmissão cultural e estruturação do pensamento nas demais disciplinas.

Forquin (1993) também coloca a contribuição que o conceito de cultura proporciona para a compreensão das práticas e de situações escolares, denominando esta cultura pelo conceito de cultura da escola. Carvalho (2006) explica que a cultura da escola pode ser vista como uma relativização da cultura escolar (que parte de determinações exteriores) devido ao conjunto de fatores organizacionais e processos sociais específicos

2 Julia, D. (2001). A cultura escolar como objeto histórico (G. Souza, Trad). Revista Brasileira de História da Educação, 1, 9-44. (Obra original publicada em 1995). Recuperado de http://www.rbheold.sbhe.org.br/index.php/ rbhe/article/viewFile/273/281 
desse espaço e que, portanto, demonstram que a escola não é um receptáculo passivo, mas, ao contrário, atua ativamente na reinterpretação e operacionalização de instruções exteriores.

Compreender as práticas e situações escolares requer refletir sobre a cultura escolar, pensando a escola como pertencente a uma instituição global com normas e estruturas formalizadas, que se constituem no decorrer da história, mas também sobre a cultura da escola, configurada pela identidade e relações particulares de seus atores.

\section{Ler e escrever: práticas socioculturais e escolarizadas}

Vigotski compreende o homem como um sujeito social e que, portanto, se desenvolve pela interação com o mundo social (que possibilita a internalização de novas funções psíquicas). Dessa forma, o conhecimento advém de experiências externas pelo processo de apropriação cultural, sendo a aprendizagem, que ocorre pelas relações com os sujeitos e o ambiente, mediada por instrumentos culturais, como a linguagem.

Considerando o papel da aprendizagem, seja ela escolar ou não, como estímulo ao desenvolvimento, Vigotski (2014) propõe o conceito de zona de desenvolvimento proximal (ZDP). Para ele, "o processo de desenvolvimento não coincide com o da aprendizagem, o processo de desenvolvimento segue o da aprendizagem, que cria a chamada área de desenvolvimento potencial" (p. 116). É na distância entre o que já se sabe (nível real) e o que se pode saber com a ajuda do outro que é possível o desenvolvimento do indivíduo.

Para Vigotski (2008), conceito é o significado de uma palavra, e seu desenvolvimento mais do que um simples hábito mental, é na verdade um ato real e complexo de pensamento que pressupõe o amadurecimento de muitas funções intelectuais como a abstração, atenção deliberada, memória lógica, entre outras. Ele diferencia os chamados conceitos científicos, que são desenvolvidos por meio da educação escolar formal, dos conceitos espontâneos, que estão relacionados com a vivência cotidiana. Compreender o desenvolvimento de conceitos requer entender a interdependência existente entre conceitos científicos (não-espontâneos) e espontâneos.

Apesar desses conceitos se desenvolverem em direções opostas, eles estão intimamente inter-relacionados. Gaspar (2014) explica que "a aprendizagem de conceitos científicos depende do domínio dos conhecimentos espontâneos correlatos: quando há esse domínio, a aprendizagem ocorre, quando não, a aprendizagem não ocorre” (p. 133). Assim, os conceitos espontâneos precisam ter alcançado certo nível para ser possível absorver um conceito científico correlato (Vigotski, 2008).

No contexto da Ciência algumas palavras são utilizadas com significados específicos. A compreensão de um texto científico, por exemplo, requer ter conhecimento sobre conceitos específicos. Na perspectiva apontada por Vigotski (2008), o desenvolvimento desses conceitos não está relacionado apenas à repetição ou explicação do significado das palavras, mas na aprendizagem pelo contato com situações nas quais se utilizam esses conceitos, ou seja, na aproximação dos conceitos científicos 
com situações mais concretas.

Segundo Hedegaard (1996) o ensino deve buscar o envolvimento dos alunos em novos tipos de atividade que possibilitem criar zonas de desenvolvimento proximal, assim, relacionando conceitos científicos a conceitos espontâneos será possível desenvolver novas habilidades e possibilidades para ação. Ler e escrever em aulas de Física pode potencializar atividades da disciplina ao proporcionar, por exemplo, operar de diferentes formas dentro da zona de desenvolvimento proximal, favorecendo que o estudante se torne mais consciente de seus conceitos espontâneos pela descrição verbal, ao mesmo tempo em que aproxima os conceitos científicos da sua vivência cotidiana, atribuindo sentidos no nível mais concreto.

É importante nas aulas de Física enfatizar não só a escrita formal de conceitos físicos, mas a escrita produção. Na escola, muitas vezes, tendemos a tirar os espaços de narração pessoal do aluno sobre os conhecimentos, fazendo-o operar sobre conceitos estudados apenas das formas mais tradicionais (como definir, descrever, caracterizar etc.), ou seja, tomamos a escrita como uma operação do conhecimento em que é desviada a ênfase em acontecimentos cotidianos, em benefício de uma abordagem categorial (Goés, 2001).É potencial para a aprendizagem buscar situações que enfatizem a expressão do estudante com relação à sua subjetividade e cotidiano buscando aproximar conceitos espontâneos e não espontâneos também pela expressão verbal do seu pensamento.

De modo semelhante ao pensamento de Vigotski, Bakhtin (1992) concebe a palavra como signo e a compreende dentro do campo da significação humana. Porém, enquanto Vigotski (2008) busca estabelecer relações entre o pensamento e a linguagem, Bakhtin analisa a linguagem considerando a sua utilização nas relações e acontecimentos sociais, como uma atividade humana.

Bakhtin (1992) discute questões relacionadas à linguagem, não preocupado com o sistema de formas da língua, mas tendo o enunciado como objeto. A linguagem é caracterizada, pelo Círculo de Bakhtin, com um enfoque interativo/relacional, concebendo a língua na sua integridade concreta e viva e não como objeto específico da linguística (Castro, 2010). Para Bakhtin (1992) "as pessoas não trocam orações, assim como não trocam palavras (numa acepção rigorosamente lingüística), ou combinações de palavras, trocam enunciados constituídos com a ajuda de unidades da língua” (p. 297). Portanto, o enunciado se difere da oração e é considerado como a unidade real da comunicação verbal. A utilização da língua nas diferentes esferas de atividades humanas sempre ocorre por enunciados (orais e escritos) concretos e únicos.

Cada esfera de comunicação tem seus enunciados específicos e relativamente estáveis, chamados gêneros do discurso, nos quais o conteúdo temático, estilo e construção composicional se fundem indissoluvelmente (Bakhtin, 1992). O conceito de gênero não se limita a estruturas ou textos, mas implica dialogismo e modos de entender e enfrentar a vida (Brait, \& Pistori, 2012). Em atividades de comunicação verbal sempre usamos de gêneros do discurso, ou seja, de enunciados que têm certa forma padrão.

De acordo com o pensamento bakhtiniano, só é possível dominar um determinado 
gênero do discurso pela experiência com ele. Para Bakhtin (1992), uma pessoa que não conviveu em certa esfera da atividade humana, não terá o domínio de seu repertório de gêneros do discurso, já que a aprendizagem de um determinado gênero ocorre pela experiência e contato com estes tipos de enunciados.

Sob a perspectiva da natureza dialógica da linguagem, um enunciado nunca está isolado de outros, na realidade ele é sempre uma resposta a enunciados anteriores. Segundo Bakhtin (1992) "o enunciado está repleto dos ecos e lembranças de outros enunciados, aos quais está vinculado no interior de uma esfera comum da comunicação verbal" (p. 316). Assim, se analisarmos um texto escrito como um enunciado, ele é construído a partir de diferentes vozes, e a sua compreensão ocorrerá pela atitude de resposta ativa e também dependerá do contexto sócio-histórico do leitor e de suas experiências anteriores com outros enunciados. Portanto, diferentes leitores podem atribuir diferentes sentidos para um mesmo texto, assim como elaborar diferentes enunciados como resposta.

O discurso (seja oral ou escrito) é constituído pela alteridade de vozes. Algumas vezes essas vozes estão tão revestidas da compreensão do sujeito que não é possível identificar esse encontro vocal delimitando-as, por exemplo. Para além da compreensão da constituição dos textos escritos, o referencial bakhtiniano dá suporte para pensar a voz dos sujeitos como ponto de vista ou perspectiva pessoal, isso porque os sujeitos são responsivos ${ }^{3}$ e, ao mesmo tempo, dialogam com diferentes vozes e também determinados por um contexto extraverbal.

De acordo com Bubnova (2011), para Bakhtin as vozes personalizadas "representam posições éticas e ideológicas diferenciadas em união e intercâmbio contínuo com as demais vozes" (p. 270). A voz aparenta ser subjetiva, e pode ser compreendida desta forma, enquanto resposta irrepetível de um sujeito situado em uma posição única socio-historicamente. Todavia, os sujeitos estão cercados por diversas vozes que incorporam a sua voz, numa ressonância dialógica. Neste estudo, através de entrevistas, são analisadas as perspectivas (vozes) de diferentes sujeitos escolares (professor e alunos) sobre as contribuições e dificuldades das atividades envolvendo leitura e escrita em aulas de Física. Trata-se da resposta destes diferentes sujeitos às atividades desenvolvidas no contexto escolar. Uma compreensão mais profunda sobre estas diversas perspectivas é possível quando se considera que a alternância vocal é integrante do processo de estruturação de nossas interações (Castro, 2014).

\section{Objetivo}

O objetivo desta investigação é analisar as perspectivas de diferentes sujeitos professor de Física e estudantes do Ensino Médio - de um contexto escolar sobre as contribuições e dificuldades de práticas de leitura e escrita em aulas de Física, tecendo reflexões à luz dos conceitos de cultura escolar e da escola (Forquin, 1993). Entende-se

3 Em Bakhtin os sujeitos são constituídos em sua relação com o outro. A singularidade/ individualidade dos sujeitos está na pluralidade das suas vivências, que o situam em um lugar único de resposta. 
que desta forma será possível ampliar os resultados já publicados na literatura da área acerca desta temática.

A partir de Bakhtin compreende-se a voz dos diferentes sujeitos sobre as atividades desenvolvidas neste contexto escolar como suas respostas individuais às mesmas, portanto perspectivas particulares dos sujeitos, que na análise geral sobre o objeto deste estudo fortalecem, complementam ou confrontam-se.

Para atingir o objetivo geral, as análises foram realizadas em três Etapas, aqui denominadas A, B e C:

A) Caracterizar quais práticas de leitura e escrita estão presentes nestas aulas de Física, buscando compreender as contribuições e dificuldades destas práticas no processo de ensino e aprendizagem, segundo as vozes do professor e dos alunos;

B) Caracterizar como professor e alunos se relacionam com outro modo de utilização ${ }^{4}$ da leitura e da escrita de textos nas aulas de Física, buscando compreender as contribuições e dificuldades do uso da leitura e da escrita deste outro modo, segundo as vozes do professor e dos alunos;

C) Analisar como a cultura escolar e da escola influenciam na relação do professor e dos alunos com as práticas de leitura e escrita em aulas de Física.

\section{Metodologia}

Esta pesquisa é de natureza qualitativa, situada no contexto da descoberta, ou seja, trata-se, como caracterizado por Van der Maren (segundo Lessard-Hébert, Goyette, \& Boutin, 1990) de um processo indutivo exploratório e de formulação de teorias interpretativas e prescritivas.

A definição do campo empírico teve como critério a aproximação a uma sala de aula onde o professor fosse licenciado em Física, atuante na rede estadual de ensino como efetivo (concursado) - pela estabilidade no local de trabalho - e com um perfil inovador, aberto a mudanças.

Segundo Lessard-Hébert, Goyette e Boutin (1990), um dos meios de validação instrumental da pesquisa qualitativa é a confrontação de dados construídos a partir de uma triangulação entre técnicas, utilizada nesta investigação. Por isso, busca-se sobre o mesmo espaço e acontecimentos construir interpretações a partir de diferentes perspectivas: do observador, do professor e dos estudantes participantes.

Inicialmente foram realizadas observações durante um bimestre letivo em três turmas de terceiro ano do Ensino Médio, a fim de compreender de que modo enunciados escritos estavam presentes nas aulas de Física, num movimento de aproximação à cultura

4 A caracterização da presença da leitura e da escrita no contexto escolar investigado (Etapa A), a partir da observação não participante, indicou que a leitura é usada em buscas de informações não sendo realizado um trabalho mais efetivo sobre esta prática. A escrita, por sua vez, está presente em anotações, avaliações e relatórios experimentais, se aproximando da perspectiva de um veículo de comunicação pedagógica (Carvalho, \& Barbeiro, 2013). Neste trabalho, a expressão "outro modo de utilização" refere-se ao uso da leitura e da escrita de uma forma diferente daquela até então observada naquele contexto, ou seja, na construção, e não apenas expressão ou memorização do conhecimento na disciplina Física. 
da escola em relação ao ler e escrever naquelas aulas, trazendo subsídios para construir as interpretações relacionadas à Etapa A. Após as primeiras semanas e em acordo com o professor, foi proposta uma atividade didática a ser desenvolvida em sala de aula, dentro do tempo disponível, adotando a leitura e a escrita de textos de um modo não usual até então nas aulas acompanhadas, permitindo construir dados para responder às Etapas B e C. Tal atividade foi denominada "Desenvolvimento do Eletromagnetismo". Finalmente foram realizadas, ao final do bimestre letivo, entrevistas semiestruturadas e individuais com 14 estudantes e com o professor da disciplina.

Nessa investigação, as entrevistas realizadas com estudantes e com o professor da disciplina têm função técnica essencial, já que a técnica de observação participante, utilizada anteriormente às entrevistas, forneceu os dados a confrontar para suscitar novas questões e interpretações (Lessard-Hébert, Goyette, \& Boutin, 1990). Para a pesquisa qualitativa que parte da técnica de observação participante, a entrevista com os sujeitos é fundamental e enriquecedora da investigação. Segundo citam Lessard-Hébert, Goyette e Boutin (1990), a técnica da entrevista possibilita ao investigador, após a observação participante, "confrontar a sua percepção do "significado" atribuído pelos sujeitos aos acontecimentos com aquela que os próprios sujeitos exprimem" (p. 160). No presente artigo as análises são realizadas sobre os dados constituídos através da observação e, sobretudo, das entrevistas, que revelam as perspectivas dos sujeitos sobre o objeto desta investigação.

Para a entrada no campo empírico, foram feitos contatos e apresentação da pesquisa ao professor de Física e a Coordenadora Pedagógica da escola, obtendose autorização para desenvolver a investigação nas aulas de Física. Foram explicados aos alunos os objetivos da pesquisa e que a sua participação era livre e voluntária. Um Termo de Consentimento Livre e Esclarecido (TCLE) foi enviado aos pais e responsáveis de todos os alunos das três turmas, para que pudessem tomar ciência da investigação e autorizar a participação dos estudantes. Do total de 96 alunos, 44 trouxeram o termo com a autorização dos responsáveis. Apesar de já ter o TCLE assinado pelos responsáveis, tomou-se ainda o cuidado de, aos 14 estudantes que se dispuseram a participar das entrevistas, apresentar um novo TCLE, para sua compreensão sobre o processo e manifestação pessoal de participação voluntária. O professor participante também assinou um TCLE para participar desta investigação.

Para analisar as entrevistas, compreendendo a linguagem como essencialmente dialógica a partir de Bakhtin (1992), foi utilizado um dispositivo analítico proposto por Veneu, Ferraz e Rezende (2015), seguindo as etapas: 1) Identificação do enunciado (respostas às perguntas feitas pela investigadora); 2) Leitura preliminar do enunciado (identificando elementos linguísticos e estabelecendo relações com as Etapas e o objetivo de pesquisa); 3) Descrição do contexto extraverbal (o horizonte espacial comum dos interlocutores; o contexto da enunciação; quem são os sujeitos participantes etc.) e 4) Análise do enunciado (articulando o contexto extraverbal com elementos linguísticos para responder ao objetivo geral da investigação). A escolha desse dispositivo analítico 
está relacionada ao diálogo (busca de coerência) com o referencial teórico de Bakhtin, segundo o qual embasamos nossas análises e interpretações. As interpretações das falas são organizadas segundo as semelhanças observadas nos enunciados desses estudantes e do professor, nas entrevistas.

\section{Elementos do contexto extraverbal: perfil da escola, do professor e dos estudantes}

O colégio no qual a pesquisa foi realizada está localizado na capital de um estado da região Sul do país, em um bairro de classe média, cerca de seis quilômetros do centro da cidade - considerado não distante do centro, dada as dimensões da capital - e oferece Ensinos Fundamental, Médio e Profissionalizante, sendo reconhecido na comunidade pela sua boa estrutura física e ações/projetos extracurriculares.

$\mathrm{Na}$ época da realização desta pesquisa o professor colaborador era Licenciado em Física há 14 anos e atuava na rede estadual de ensino há 12 anos. Iniciou como contratado pelo PSS (Processo Seletivo Simplificado) e há 11 anos atua como concursado no colégio onde essa investigação foi realizada. Concluiu um curso de especialização em Tecnologias Aplicadas à Educação, além de outros cursos de extensão universitária. Participava dos cursos de Formação Continuada oferecidos pela Secretaria de Educação do estado, apesar de indicar em sua fala certa crítica às metodologias utilizadas nessas formações.

Desde que começou atuar neste colégio, ele abre espaço em suas aulas para supervisão de estagiários e trabalhos de pesquisa da universidade, além de ser supervisor de bolsistas do PIBID (Programa Institucional de Bolsas de Iniciação à Docência). Trata-se de um professor aberto a novas ideias e diálogo com a universidade, buscando atualização e inovação nas suas aulas.

Em diferentes momentos de formação (inicial e continuada) o professor teve oportunidade de refletir e discutir o uso da leitura e da escrita de textos na escola e em aulas de Física. Ele se recordou que, durante a graduação participou de discussões em uma disciplina de Metodologia de Ensino de Física, na qual foram feitas reflexões sobre a leitura e a escrita, sendo que ele se atentou mais à produção textual pelo fato de ter apresentado um seminário sobre a temática. Mencionou também discussões não voltadas especificamente à disciplina Física, durante cursos de formação continuada na escola. Ele participou de um Simpósio em 2006 no qual ocorreram discussões sobre questões referentes à leitura de textos literários relacionados com Ciência. Mencionou ainda uma participação recente (no mesmo ano em que a entrevista foi realizada) em um Workshop do PIBID no qual foi discutida a necessidade de todas as disciplinas escolares trabalharem com a leitura e a escrita de textos em suas aulas.

Em relação aos estudantes participantes das entrevistas, ressalta-se que eles não foram escolhidos previamente por possuírem um determinado perfil. Isto favoreceu uma diversidade, inclusive com relação aos seus hábitos e gostos pela leitura e escrita de textos no cotidiano. Cada um possui seus objetivos e características particulares, vindo 
de culturas e vivências diferentes. Para preservar o anonimato eles serão indicados ao longo deste texto por meio dos códigos A1, A2, A3, A4, A5, A6, A7, A8, A9, A10, A11, A12, A13 e A14.

Cada turma tinha em torno de 30 alunos, cerca de 90 no total. Foram entrevistados 14 deles, tendo como critério que o aluno tivesse participado de alguma das aulas nas quais foram desenvolvidas as atividades de leitura de textos do livro didático e escrita da carta a um cientista, que ele se dispusesse a participar voluntariamente da entrevista e que seus pais ou responsáveis tivessem assinado o TCLE. Foram cinco estudantes da turma A (A2; A3; A4; A7 e A13); três da turma B (A1; A9 e A11); e seis da turma C (A5; A6; A8; A10; A12 e A14), todos na faixa etária entre 16 e 18 anos. Todos eles mencionaram que pretendem continuar estudando após o Ensino Médio, em curso técnico ou graduação.

A maioria deles afirmou que gosta de ler (A2; A3; A4; A7; A8; A9; A10; A13 e A14), e dentre estes, alguns ainda citam a leitura como atividade que realizam nas horas vagas (A3; A4; A7; A8 e A14), o que pode ser interpretado como uma maior afinidade desses alunos com a leitura de textos.

Elementos que particularizam cada estudante serão resgatados ao longo das análises de seus enunciados, trazendo o seu contexto extraverbal para a reflexão.

\section{Análises e resultados}

As análises e interpretações serão apresentadas em torno das três Etapas (A, B e C) norteadoras, visando atingir o objetivo geral desta investigação. Na Etapa A são analisadas as vozes dos sujeitos em relação às práticas de leitura e escrita identificadas no contexto da investigação (cultura da escola). Na Etapa B, suas vozes em relação às práticas de leitura inseridas pela pesquisadora naquele contexto (num outro modo de utilização da leitura e escrita). Na Etapa C, são retomados e discutidos novos elementos sobre as perspectivas dos sujeitos participantes que permitem analisar como a cultura escolar pode estar influenciando na forma com que os sujeitos se relacionam com tais práticas.

\section{Etapa A: Leitura e escrita presentes na cultura escolar de Física: contribuições e dificuldades segundo a voz dos sujeitos}

Atividades de leitura de textos em sala de aula não foram utilizadas com frequência nas aulas observadas. O professor geralmente incentivava os alunos a fazerem buscas e leituras individuais prévias (não obrigatórias), para discutir os conceitos posteriormente em sala de aula. Assim, embora a leitura para aprender Física não tenha sido explicita e intencionalmente explorada, ela era uma possibilidade aos estudantes já que eles podiam e eram incentivados a buscar informações através de leituras no contexto extra-aulas. Porém, cabia a cada um a iniciativa e responsabilidade de buscar textos adequados aos seus interesses, podendo optar por outras formas de acesso à informação.

Atividades de escrita, por sua vez, têm maior destaque nas práticas deste contexto, pois o professor incentivava que os alunos tivessem uma caderneta na qual fizessem 
anotações sobre os conteúdos estudados, não sendo permitidas cópias de exercícios resolvidos. Durante as avaliações escritas eles podiam consultar essa caderneta com as suas anotações, feitas durante ou após as aulas.

O conteúdo estudado no bimestre em que esta investigação foi realizada era o eletromagnetismo e o professor optou por trabalhar com experimentos desenvolvidos e apresentados pelos estudantes em forma de seminários em grupos. Os estudantes buscaram os materiais e realizaram toda a construção do experimento. $\mathrm{O}$ professor disponibilizou roteiros para cada experimento com indicações de textos explicativos (prática de leitura não obrigatória) e vídeos do YouTube, além de tópicos de um roteiro/ relatório que deveria ser escrito pela equipe (prática de escrita não obrigatória).

$\mathrm{Na}$ sequência os resultados e análises são explicitados a partir destas diferentes atividades desenvolvidas no bimestre: (i) Buscas e leituras individuais prévias às aulas, (ii) Anotações individuais na caderneta e (iii) Apresentação da Atividade Experimental: leitura do texto base e escrita do roteiro.

\section{(i) Buscas e leituras individuais prévias às aulas (não obrigatórias)}

$\mathrm{Na}$ entrevista o professor apontou como uma falha o fato de não incentivar tantos momentos de leitura em suas aulas, no sentido de não ensinar a interpretar os textos de Física.

Professor: Então, são pouquíssimos momentos, assim, que eu faço a leitura com eles, eu vejo que eu peco neste ponto, eu tenho que ensinar um pouco mais a interpretar os textos de física.

Para ele, o fato de muitos alunos terem dificuldades com a interpretação de textos faz com que a leitura seja um processo complementar na aprendizagem, já que em sala de aula tornam-se necessárias mediações para que o estudante compreenda o texto e os conceitos de Física. A expressão "eu peco neste ponto" sugere que o professor, talvez influenciado pelo que supunha ser a expectativa de sua interlocutora (a entrevistadora), reconheceu que práticas de leituras são necessárias, dando ao seu enunciado uma entonação de autocrítica sobre a sua atuação em sala de aula. Assim, ainda que ele reconheça a importância deste tipo de prática, a mesma não é usual em suas aulas.

Entende-se que a dificuldade dos estudantes com o vocabulário/ interpretação do texto, que será retomada mais à frente, pode aproximá-los de explicações sobre esses conceitos por recursos audiovisuais. Os alunos entrevistados também foram questionados sobre a realização de buscas em outras fontes de informações, fora da sala de aula. Há alunos (A13, por exemplo) que gostam de ler e, mesmo assim, preferem assistir vídeo aula na internet quando têm dificuldade de compreensão de conceitos na disciplina:

Entrevistadora: Mesmo quando tem dificuldade para compreender?

A13: Ah, sim daí eu busco na internet, ou talvez uma vídeo aula. Geralmente vídeo aula. Nesse caso eu já não procuro nada já escrito. A não ser que seja um trabalho, que eu 
tenha que realizar um trabalho, daí sim.

Apenas A1 afirmou que não fazia buscas de informações no contexto extraclasse. Os demais estudantes afirmaram que faziam leituras sobre os conceitos estudados quando se interessam pelo assunto (A2 e A5); quando sentem dificuldades para compreender (A3, A6, A10, A11, A13 e A14) ou ainda quando precisam estudar para uma prova (A4, A12, A7, A8 e A9).

Nenhum dos alunos mencionou leituras e busca de informações no livro didático que eles possuem em casa ${ }^{5}$. Quando sentem necessidade, utilizam em geral as buscas na internet. Percebe-se que a maioria dos estudantes entrevistados realizam essas buscas de informações não motivadas pelo seu interesse pelo assunto, mas, sobretudo, quando sentem dificuldades ou necessidade de melhor compreender algum tema para uma avaliação escolar.

Assim, essesdadosevidenciamqueasleiturasebuscasindividuais podem contribuir para os estudantes acessarem mais informações (quando se interessam pelo assunto) e melhor compreender os conteúdos estudados em sala (quando sentem dificuldades ou haverá avaliação). As dificuldades mencionadas referem-se à interpretação de textos pelos estudantes que, em alguns casos, preferem obter informações por áudio e vídeo em detrimento de textos escritos.

\section{(ii) Escrita em anotações individuais realizadas em uma caderneta}

Em relação à escrita em anotações individuais realizadas na caderneta, na voz do professor, os alunos que preparavam a caderneta geralmente não precisavam consultála, pois o ato de escrever se configura como estudo e compreensão do conteúdo:

Professor: Então eu peço pra eles na caderneta também anotar o que é aquela fórmula, o que significa cada letrinha da fórmula, qual a unidade que se usa. Então quando o aluno faz realmente tudo isso, tem alunos que chegam ao final da prova e falam assim: Professor, eu coloquei tudo isso na caderneta e nem usei a caderneta. Daí eles começam a perceber que o fato de eles escreverem na caderneta, ele já está estudando e não decorando para fazer a prova. Ele está lembrando o que é aquilo ali.

Neste trecho o professor incorporou o discurso indireto dos estudantes que ficou submetido à sua voz, buscando fortalecer a sua argumentação. Em sua opinião, permitindo o uso da caderneta durante a avaliação, seria possível avaliar o raciocínio do estudante e não se ele decorou informações, pois isso se tornaria dispensável já que o estudante poderia consultar as informações, se essas tivessem sido escritas previamente na caderneta. Essa dimensão da importância do registro escrito para estudar a matéria posteriormente e preparar-se para provas e testes também é evidenciada no estudo de Paula e Talim (2015).

Considerando a escrita como um ato complexo de organização do pensamento

5 Embora não se constitua objetivo deste texto, vale a pena mencionar que este é um resultado sobre o qual é importante se refletir; principalmente considerando que há um grande financiamento por parte do governo federal em programas tais como o Programa Nacional do Livro Didático - PNLD. 
(Vigotski, 2008), a escrita na caderneta pode ser compreendida como um importante

momento de reflexão sobre o que é importante anotar e o conteúdo em si, e estruturação do pensamento com relação aos conceitos estudados, pois o estudante precisa compreender o que está escrevendo e criar suportes para sua leitura posteriormente.

Quando questionados na entrevista sobre sentir necessidade de anotar e esquematizar conceitos na caderneta mesmo sem a solicitação do professor, a maioria dos estudantes (A1; A3; A4; A5; A7; A13; A8; A9 e A14) afirmou que fazia anotações. Segundo os enunciados de alguns deles, anotar contribuía de diferentes formas: ajuda a prestar atenção na aula e memorizar as informações (vide enunciado de A8, por exemplo), o que corrobora, em certa medida, a apropriação feita pelo professor do discurso dos estudantes, no trecho anterior.

A8: Sim. Porque... eu, a prova, até pra prestar atenção, eu tenho que ter algum foco e quando eu estou anotando eu exijo de mim mesma prestar atenção naquilo. E anotação também ajuda muito depois, porque mesmo que o professor fale e eu entenda na hora, depois eu nunca vou lembrar do jeito que ele falou ou da forma como ele explicou. Então eu sempre procuro fazer anotações. [...]. Então é muito bom porque às vezes você anota e você nem lembra daquilo depois e na prova você pode usar essa agenda. $\mathrm{E}$ daí... você vê as anotações e fica muito mais claro, muito mais fácil de você lembrar do conteúdo do que foi passado na aula.

A13: É de Física e de todas as matérias, eu acho. Você fala ali eu, você escrever o que o professor fala te ajuda a recordar mais pra frente da aula já dada, você não precisa talvez ter esforço maior aí, de ficar pesquisando alguma coisa.

A14: Porque me ajuda. Porque daí eu não me esqueço, eu tenho que decorar as coisas anotando porque se eu não anotar eu vou esquecer daquilo, então eu tenho que anotar, senão...

$\mathrm{Na}$ escrita da caderneta, as anotações eram feitas porque podiam auxiliar o aluno na prova, como exemplificado nas falas dos alunos A8, A13 e A14. Isto porque, em suas perspectivas, anotar os ajudava a memorizar o conteúdo.

Nessas vozes há uma potencialidade, porém também certa limitação, por não conceber a escrita como atividade intelectual (Vigotski, 2008). Mais do que memorizar o conteúdo, o pensamento existe, sobretudo, pelas palavras (Vigotski, 2008), escrever pode requerer tomar consciência sobre o próprio ato de pensamento, de tal modo que a escrita pode ser concebida como processo de reflexão, organização e estruturação do pensamento, mais do que um simples ato mecânico de escrita de letras, para memorizar o conteúdo.

$\mathrm{O}$ aluno A12 em um dos seus enunciados durante a entrevista apontou uma dificuldade em relação à escrita "livre" na caderneta, a partir das explicações do professor. O enunciado desse aluno também traz elementos para reflexão sobre a cultura escolar:

A12: Então, eu acho que o professor devia assim... não sei... passar mais no quadro 
assim, conteúdo assim mais explicado por conceito. Acho que assim ficaria melhor, do que a gente pesquisar ou tipo ele falar e a gente escrever. Porque eu não consigo prestar atenção nele falando e escrever ao mesmo tempo.

A fala de A12 mostra também a individualidade de cada estudante. Se para alguns alunos escrever na caderneta ajuda a prestar atenção na aula, para A12 as duas ações simultâneas atrapalham sua concentração (confrontando também a perspectiva positiva apresentada pelo professor). As suas expressões "passar mais no quadro" e "mais explicado por conceito" podem ser interpretadas como críticas à metodologia adotada pelo professor que não contemplava esse tipo de prática. Usualmente as discussões que o professor promovia em sala de aula ocorriam sem sistematizações no quadro de giz. Por um lado, essas sistematizações/definições conceituais demandadas por A12 podem ser importantes no movimento de aproximação de conceitos espontâneos e científicos (Vigotski, 2008), mas por outro lado, podem retratar práticas fortemente presentes na cultura escolar (que sem os devidos cuidados podem se limitar à reprodução mecânica).

Assim, na visão dos alunos, as contribuições da prática da escrita em uma caderneta eram: manter a atenção nas explicações, memorizar informações e estudar/compreender o conteúdo. As dificuldades decorriam de visões limitadas sobre a funcionalidade da escrita (baseada na memorização de conteúdos) e a cultura escolar, uma vez que alguns alunos sentiam falta do professor esquematizar no quadro os conteúdos para serem copiados na caderneta.

\section{(iii) Apresentação da Atividade Experimental: leitura do texto base e escrita do roteiro}

Em relação à leitura do texto base indicado pelo professor para o desenvolvimento da atividade experimental, na entrevista os alunos foram questionados se haviam realizado tal leitura. A maioria afirmou que não acessou os links indicados pelo professor, mas que fez buscas na internet, utilizando a ferramenta de pesquisa Google para encontrar informações em sites, através de textos, imagens ou vídeos. Apenas três dos alunos entrevistados (A3, A7 e A8) afirmaram que fizeram a leitura do texto recomendado, todavia também buscaram informações em outras fontes porque tiveram dificuldades de interpretação do texto:

A7: Busquei. Porque eu não tava conseguindo fazer, daí eu tinha que pesquisar.

A8: Li. Não entendi muito bem, mas eu li.

Entrevistadora: Por que você não entendeu muito bem?

A8: Porque eu achei meio confuso. Que nem, a leitura de física pra mim não é uma leitura que eu vá entender, porque eu acho meio confuso, mas ajudou na explicação porque quando tinha que explicar para o professor, através do que eu tinha lido, eu consegui transmitir algumas coisas. Mas pra mim, o vídeo ficou muito mais claro. [...] Eu pesquisei outros sites, outras maneiras de explicar também, mais fáceis, mais simples, 
um resumo. E daí consegui, foi mais a parte de apresentar.

O aluno A8 expressou, de modo mais claro, dificuldades na leitura de textos relacionados à Física, o que o levou a buscar informações em outras fontes e em outro suporte, neste caso o vídeo. Considerando o contexto extraverbal, A8 tem afinidade com leitura, inclusive em horas vagas, e mesmo assim afirmou: "não é uma leitura que eu vá entender" ou ainda "eu acho meio confuso". Em "não é uma leitura que eu vá entender", pode-se interpretar que não se trata de um problema deste texto específico, mas de textos da área, isto é, se forem propostos outros textos de Física, ele terá dificuldades também. Trabalhos como de Almeida, Silva e Babichak (1999) e Silva (2013) evidenciam dificuldades dos estudantes na produção de sentidos para a leitura em aulas de Física, que também estão relacionadas com a não compreensão de conceitos. Ao mesmo tempo, este mesmo estudante diz que a leitura do texto indicado pelo professor e um resumo o ajudaram na apresentação, indicando que o texto escrito pode tê-lo auxiliado por ser um material de fácil consulta na sua explicação oral sobre o experimento para a turma.

Pelo relato dos outros estudantes, a leitura de textos, não necessariamente os indicados pelo professor, foi a principal fonte de informações que auxiliou na compreensão dos experimentos. Na entrevista, o professor confirmou que alguns alunos foram além do solicitado (como foi evidenciado na fala dos alunos), buscando diversas leituras para realizar a atividade.

Professor: Apesar de ter dado pronto pra eles com referência e tudo, teve gente ali que eu vi que foi além, procurou outras referências. E, teve aluno que procurou outras por ele não entender aquilo que eu já tinha dado pro aluno. [...] Os alunos realmente se importaram em aprender, em entender, o que estava acontecendo ali.

Neste caso, a incorporação indireta do discurso dos alunos na voz do professor pode levar à interpretação de que a busca por outras referências, por alguns alunos ("teve gente ali"), se deu pelo interesse dos estudantes na atividade desenvolvida. Os enunciados anteriores dos alunos mostram que, em alguns casos, como o professor também ressalta em sua fala, a busca se deu pela dificuldade de compreensão dos conceitos por uma fonte específica (o texto escrito indicado pelo docente), porém, de fato, a maioria dos estudantes se empenhou em buscar diferentes meios de informação. Esses dados também evidenciam certas transformações na forma como os estudantes se relacionam com as atividades escolares, devido ao fácil acesso às informações por meio da internet.

Em síntese, a contribuição da leitura do texto base indicado pelo professor para o desenvolvimento da atividade experimental foi auxiliar na apresentação dos experimentos para a turma. Entretanto, ressalta-se que só três dos estudantes entrevistados leram o texto recomendado, com dificuldades de interpretação. Portanto, mais uma vez foram enfatizadas dificuldades de interpretação de textos pelos alunos e a preferência por obter informações por pesquisas na internet, por áudio e vídeo.

Acerca da escrita do roteiro experimental para a apresentação dos seminários sobre os experimentos de eletromagnetismo, embora não fosse de entrega obrigatória, 
muitos alunos optaram por fazê-lo. Dos alunos entrevistados a maioria (A3, A4, A5, A8, A9, A11, A13 e A14) escreveu o roteiro para a apresentação. Os alunos que não escreveram o roteiro explicaram que não sentiram a necessidade de organização das ideias, pelo fato de o experimento ser simples.

$\mathrm{O}$ relato desses alunos indica que, para eles, escrever o roteiro foi importante por diversos motivos: Ajuda a compreender e organizar as ideias (A2, A9 e A14), como um "passo a passo" do que devia ser feito (A4, A8, A11 e A13) ou para o professor avaliar a atividade (A5). Assim, os alunos atribuíram diferentes sentidos para a escrita do roteiro experimental.

Nos enunciados dos estudantes sobre o roteiro experimental aparecem elementos para discussão sobre a influência da cultura da escola nas suas perspectivas.

A4: Foi, porque assim, com aquelas perguntinhas mais diretas, você acaba entendendo muito mais o assunto.

A5: Sim, porque o professor precisa avaliar né, o que a gente entendeu. Porque não é só chegar com o experimento lá e falar o que você viu no vídeo, precisa procurar um algo mais sobre...

O aluno A5, por exemplo, em uma análise do contexto extraverbal, indicou não possuir o hábito de realizar leituras e anotações nas aulas de Física, mas que considerava o roteiro importante porque o professor necessitava de uma forma para avaliar a atividade. Parece que esse aluno concebia o roteiro experimental como uma prática pertencente e necessária ao cumprimento das normas escolares, mas não como um processo que auxiliasse sua aprendizagem, visão da escrita semelhante a um veículo de comunicação pedagógica (Carvalho, \& Barbeiro, 2013). Nas práticas escolares da disciplina Física, o roteiro experimental conjuntamente a esse tipo de atividade pode ser considerado uma prática tradicional, fazendo com que os alunos o entendam como algo pertinente nesta disciplina. Tal estudante também faz relação na sua fala com o uso de vídeo para realizar a atividade ("falar o que você viu no vídeo"), e não com o texto escrito recomendado. Em relação à fala de A4, a expressão "com aquelas perguntinhas mais diretas" também remete a existência de uma cultura (Forquin, 1993) sobre as atividades escolares, que será retomada adiante na discussão da Etapa C.

Os outros estudantes, que consideraram a escrita do roteiro importante, de alguma forma relacionam essa prática à sua aprendizagem: como um guia para a apresentação ou ainda por possibilitar a organização e compreensão acerca do trabalho. É possível interpretar que o roteiro possibilitou orientar o olhar do estudante e o processo de escrita tornou possível sistematizar e organizar as diversas informações (Vigotski, 2008) que eles encontraram.

Assim, a escrita do roteiro contribuiu para compreender e organizar as ideias, um guia para a apresentação oral, para expressar conhecimentos e para o professor avaliar a atividade. As dificuldades mencionadas foram não sentir a necessidade da escrita e a visão limitada sobre a funcionalidade da escrita (a necessidade de questões guias/ 
modelo a ser seguido), limitação esta que parece ter relação com a Cultura Escolar no que se refere às práticas na disciplina Física.

\section{Etapa B: Leitura e escrita de textos de outro modo: Contribuições, dificuldades e as relações dos sujeitos com as mesmas}

Buscando outra forma de utilização da leitura e da escrita em sala de aula, interferindo naquela cultura inicialmente observada, foi proposta ao professor uma atividade que foi denominada "Desenvolvimento do Eletromagnetismo", elaborada conjuntamente por pesquisadora e professor e desenvolvida pelo professor nas aulas após as apresentações dos experimentos pelos alunos.

Um primeiro esboço da atividade foi proposto pela pesquisadora, que o ofereceu ao professor para que fizesse suas alterações, se assim o desejasse. A atividade foi concebida para compor de forma orgânica e articulada o rol de atividades desenvolvidas até então no conteúdo (eletromagnetismo). Objetivava-se, em relação à leitura de textos, incentivar que os estudantes estabelecem relações para além da busca-de-informações (Giraldi, 2003 citado em Flôr, \& Cassiani, 2011, p.74). A escrita, por sua vez, para além da cópia ou resposta a questões, foi proposta como meio para expressão pessoal dos estudantes sobre os conceitos estudados.

Em termos pedagógicos, almejava-se que estas atividades auxiliassem na (re) construção dos conhecimentos pelos estudantes, como outro meio de operação com tais conhecimentos dentro da zona de desenvolvimento proximal (Vigotski, 2014). Em termos da pesquisa, buscava-se criar um contexto que permitisse analisar de que forma os estudantes se relacionariam com este outro modo de utilização da leitura e escrita nas aulas de Física.

A atividade foi desenvolvida em duas aulas. Na primeira utilizou-se a leitura de dois textos que tratavam de aspectos históricos do eletromagnetismo. Foram propostas algumas questões aos alunos, cujas respostas não estavam explícitas nos textos, mas partiam de reflexões sobre os mesmos. Os textos foram retirados do próprio livro didático de Física adotado na escola, por ser um recurso ao qual todos os alunos tinham acesso, cujo uso até então não havia sido observado em sala de aula. Os textos remetiam à história do Eletromagnetismo, abordando experimentos desenvolvidos por cientistas como Willian Gilbert, Hans Christian Oersted, Michael Faraday, André-Marie Ampère, entre outros. Alguns desses experimentos haviam sido discutidos em sala de aula previamente, nos seminários apresentados pelos estudantes. Deste modo, os textos poderiam permitir o aprofundamento de discussões já realizadas, oportunizando uma visão mais geral sobre a construção dos conhecimentos de Eletromagnetismo ao longo do tempo, a partir da contribuição de vários cientistas em diferentes épocas.

A segunda aula foi baseada na escrita de uma carta para William Gilbert, incentivando a produção textual dos alunos de uma forma mais livre, ou seja, sem a necessidade de copiar conceitos, mas escrever trazendo à tona sua subjetividade, de acordo com sua compreensão. 
$\mathrm{Na}$ sequência, apresentam-se os resultados da aplicação desta atividade, destacando a análise das vozes e das relações dos sujeitos com a (i) leitura de textos do livro didático e (ii) escrita da carta a William Gilbert.

\section{(i) Leitura dos textos do livro didático}

Em relação a esta atividade, observou-se que diante da possibilidade de alterar o esboço inicial da atividade proposta pela pesquisadora, o professor fez sugestões considerando suas percepções sobre o seu espaço de trabalho, que advinham do seu repertório de experiências. Sugeriu, por exemplo, que ao invés dos três textos inicialmente propostos pela pesquisadora, fossem realizadas leituras de dois textos apenas - os dois que tratavam de aspectos históricos - além da reformulação de algumas questões. Segundo ele, muitos alunos possuem dificuldades de concentração, perdendo o interesse pela leitura de textos longos, por exemplo. Assim, a leitura nas aulas de Física nem sempre seria motivação para a aprendizagem. De fato, quatro alunos (A1, A5, A6 e A11) afirmaram nas entrevistas não gostar de ler por falta de paciência e atenção, aspectos apontados e considerados nas sugestões do professor.

Porém, a desmotivação do aluno pode estar relacionada não só com a extensão do texto. Como apontam Almeida e Mozena (2000), a forma de trabalhar a leitura pode aumentar a aversão do estudante por essa prática e até mesmo pela ciência. Silva (1997) também aponta que é preciso pensar em como fazer para que os alunos queiram compreender os textos e ler sobre física, isto é, como fazer para que a leitura em Física não seja mais uma "leitura obrigatória" no espaço escolar, mas se aproxime da leitura de fruição (Geraldi, 2003 citado em Flôr, \& Cassiani, 2011, p.74).

$\mathrm{Na}$ entrevista, o professor afirmou ter gostado dos textos utilizados na atividade por proporcionarem uma complementação do que estava sendo discutido em sala de aula. Segundo ele, com tais textos os alunos conseguiram compreender a parte histórica sobre os experimentos discutidos anteriormente.

Professor: [...] Principalmente a parte histórica ali, que eu acho muito interessante. E que os alunos conseguem, ou conseguiram, pelo menos os que vieram me dar um feedback, conseguiram assim compreender muito bem o que realmente estava acontecendo dos fenômenos ali.

Ainda que quaisquer propostas de atividades que envolvessem leituras de texto em sala não tivessem sido observadas naquele contexto, o professor mencionou que achava interessante o aspecto histórico do conhecimento ("eu acho muito interessante"), o que pode ter influenciado na sua visão positiva sobre a atividade de leitura. Segundo o professor, para os alunos, no contexto de aplicação da atividade, parecia fazer sentido a leitura do texto naquele momento.

A partir da teoria da natureza dialógica da linguagem de Bakhtin (1992), a leitura de um texto escrito pode ser compreendida como um diálogo ativo e responsivo com um enunciado. O texto não está encerrado em si mesmo e o seu sentido é construído pelo processo interativo entre leitor e enunciado. Jobim e Souza (2008) explicam que 
a compreensão de um enunciado requer "que o interlocutor encontre o lugar dessa enunciação no contexto de suas significações anteriores” (p. 108). Daí a importância de considerar o contexto e os enunciados anteriores com os quais o leitor teve contato, para refletir sobre os diferentes sentidos atribuídos às enunciações. A proposta de leitura dos dois textos foi realizada em um contexto de atividades sobre a temática de eletromagnetismo, e a forma como o aluno interagiu com os diversos enunciados das aulas anteriores (atividades, experimentos, vídeos, esquemas, discussões, entre outros) também pode ter influenciado nos sentidos que ele construiu para a leitura sobre a temática (Bakhtin, 1992).

$\mathrm{Na}$ entrevista, os alunos foram questionados sobre a leitura destes textos durante a atividade proposta em sala. Dois deles (A2 e A13) faltaram nesta aula. Dentre os 12 restantes, seis (A4, A6, A7, A9, A10 e A12) afirmaram ter gostado desta atividade. Os motivos por eles apresentados foram: agrega novas informações (A4 e A7), o texto é claro (A6) e o interesse pela história da ciência (A9, A10 e A12). Vide, por exemplo, a fala do estudante A9:

A9: Eu gostei porque eu gosto bastante de história também. Então ele ligou tipo partes que aconteceram no passado, como que aconteceu e tal. Essa área da física para mim é muito legal.

Outros seis estudantes (A1, A3, A5, A8, A11 e A14) não gostaram dos textos e os motivos mencionados foram: a falta de interesse (A14), o texto não é claro (A1 e A3), não gosta de ler (A11) e certo desinteresse pela história da ciência (A5 e A8).

A5: Olha, eu não gosto muito de ficar sabendo das histórias de cientistas, mas... (pausa) eu só lembro que fiz atividade que, eu lembro que tinha, acho que cinco perguntas ou mais.

Tais falas evidenciam certo contraste em sala de aula devido à diversidade de interesses e sentidos que os alunos atribuíram à atividade.

Pela análise dos elementos do contexto extraverbal, considerando o perfil e os enunciados dos estudantes nas entrevistas, percebe-se que a identificação do aluno com a leitura ou temática do texto influencia o desenvolvimento deste tipo de atividade em sala de aula. Enquanto para alguns o fato de o texto tratar da história da ciência é um atrativo para a leitura, para outros é motivo de desinteresse.

$\mathrm{O}$ aluno A12, por exemplo, afirmou não gostar de ler, mas possuir interesse por História. Seu pai é professor desta disciplina, e isso pode ter feito com que gostasse da leitura dos textos propostos. Caso semelhante ocorreu com o aluno A6, que disse não ter afinidade com leitura, mas achou a atividade interessante. Outros alunos (A4, A7, A9 e A10) gostam de ler e gostaram dos textos. Assim, considerando que o processo de escolarização também insere o aluno numa nova cultura, trabalhar com a leitura pode motivar e despertar novos interesses aos estudantes.

O aluno A11, por sua vez, não tinha o hábito de ler e afirmou que não gostou dos textos justamente por esse desinteresse pela leitura. Em outros casos (A3, A8 e A14), o 
aluno gostava de ler, mas não gostou dos textos propostos.

$\mathrm{O}$ aluno A7, apesar de expressar gostar da atividade, considerou que se as questões propostas após a leitura dos textos do livro didático fossem mais focadas no texto, talvez os alunos prestassem atenção naquelas informações e as aprendessem:

Entrevistadora: Você não viu tanta relação assim...

A7: É... isso, podia ter mais coisa mais pergunta nem que fosse pergunta mais bobinhas assim, mas pra gente pegar mesmo e por no texto e ler e escrever para aprender e ler bem. Acho que é isso que eu mudaria.

Talvez porque este tipo de atividade - de perguntas com respostas focadas em informações explícitas no texto - seja mais comum na escola, acaba-se tendo a visão que é dessa forma que se aprende um determinado conteúdo, pela repetição de informações consideradas importantes.

Como ressaltado anteriormente, para o funcionamento deste tipo de prática é importante ter um contexto suficiente de significações que permita aos estudantes dialogar com o texto (Bakhtin, 1992), contexto este que pode ser criado pelo professor. No desenvolvimento da atividade, a leitura foi realizada individualmente, sem interferências, ressaltes, questionamento etc. por parte do professor. Contudo, como aponta o estudo de Assis e Teixeira (2005), além do uso de textos potencialmente significativos para a aprendizagem, a mediação do professor, adotando uma postura dialógica com os estudantes, pode despertar o interesse e motivação com relação à leitura.

O desenvolvimento desta atividade, por ser uma situação diferente à habitual naquelas turmas, pode trazer certa insegurança aos alunos e ao professor, pois altera $o$ espaço da sala de aula. Estudos da literatura como o de Assis e Carvalho (2008) apontam que, muitas vezes, diante dessa insegurança, o professor não viabiliza articulações necessárias e passa a adotar uma postura não dialógica. Chaves, Mezzomo e Terrazan (2001) também apontam que a falta de familiaridade do professor com leituras relacionadas ao tipo de texto usado dificulta a sua atuação como mediador.

O professor enfatiza em um de seus enunciados que para trabalhar com a leitura e a escrita no ensino é necessária uma formação sólida na parte conceitual da Física, pois os alunos podem ser motivados por essas práticas a questionar conceitos.

Professor: Mas daí uma atividade que nem essa que a gente aplicou aí pros alunos, a grande dificuldade é que o professor tem que ter MUITO domínio de tudo. Da parte histórica, da parte conceitual e isso a gente percebe também que há falha nos professores. Tanto no professor que acabou de sair da graduação quanto do professor que ta lá se aposentando. Dificilmente você tem um professor que realmente consegue vir $110 \%$ preparado para a sala de aula. Aí, você deve ter conversado com os alunos, a reclamação deles é: que tem professor que não deixa o aluno fazer pergunta em sala de aula. Eles têm dúvidas, mas quando eles vão fazer o professor é grosso com eles. Manda ficar quieto. E aí a dificuldade deles é essa também de conseguir responder as dúvidas dos alunos. 
Segundo o professor, apesar do discurso, muitos professores têm dificuldades para desenvolver atividades diferenciadas em suas aulas. Ele, mesmo tendo participado de alguns momentos de formação sobre a leitura e a escrita, refletiu que ainda possuía dificuldades para conceber atividades deste tipo. Outro aspecto que chama atenção sobre esse enunciado é a formação do professor para os diferentes aspectos sobre o conteúdo específico. A fala do professor conduz à interpretação de que a atividade proposta, explorando outros aspectos sobre o Eletromagnetismo, pode fomentar dúvidas e questionamentos por parte dos alunos, dúvidas estas que os professores podem não estar preparados para responder. Parece que a abordagem mais tradicional do conhecimento pode evitar essas diferentes atribuições de sentidos pelos estudantes. Nesse caso específico, o professor menciona dificuldades atribuindo-as a outros professores (em terceira pessoa), sem se incluir em sua fala.

Assim, para o professor e os alunos, as contribuições da inserção dessa prática de leitura de textos do livro didático foram: complementar discussões de conteúdos, ampliar o olhar e compreensão sobre os conceitos (História e Filosofia da Ciência) e despertar novos interesses dos alunos para a leitura ou temática do texto. As dificuldades identificadas foram as de interpretação de textos e concentração pelos alunos, falta de interesse pela leitura ou pela temática do texto, ausência de espaço para diálogo/ mediação em sala de aula, cultura escolar e a formação do professor (insegurança pela diversidade de conteúdo).

\section{(ii) Escrita de uma carta para William Gilbert}

Em relação a esta atividade, inicialmente ressalta-se que não se tinha por objetivo principal o ensino do gênero carta e não foram oferecidos modelos de escrita. Buscavase, por meio desta produção - que podia ter diferentes formas segundo a criatividade de cada estudante -, motivar a expressão e sistematização/reconstrução das ideias dos alunos sobre as discussões e leituras realizadas no decorrer do bimestre.

A análise específica das cartas produzidas pelos estudantes, pautada em Bakhtin (1992) e Vigotski (2008), foi publicada em Setlik e Higa (2017). Embora tal análise não seja foco do presente artigo, ressaltam-se brevemente alguns resultados: foram evidenciadas dificuldades de alguns estudantes em escrever sobre física e os conceitos científicos não apareceram ou apareceram de modo vago em suas escritas. Nas cartas produzidas, observou-se ainda que quatro alunos (A4, A8, A9 e A10) pareceram usar a escrita para expressão pessoal tomando diferentes vozes para si (Bakhtin, 1992), sem cópias integrais de informações de outras fontes. Estes relataram na entrevista que a atividade proporcionou a eles novas reflexões sobre o conteúdo.

Questionados sobre terem gostado ou não da atividade, aqueles que gostaram assim se expressaram:

A4: [...] Uma aula diferente porque a gente não faz essas coisas sempre e... foi legal, gostei bastante. 
A8: Ah, eu gostei. Gostei muito. Como eu falei escrever é uma coisa que eu gosto. [...].

A9: Eu achei uma experiência bem nova para uma aula de física. Eu achei uma coisa meio inovadora. Porque eu pensava... pelo menos pelo que eu estudava nos cursinhos e tal... nada nem parecido com isso, eu achei uma ideia legal.

A10: Eu achei bem legal assim, porque... a gente, idealiza um momento assim, mesmo que não possível assim, a gente poder falar com alguém que foi importante no passado, [...] foi bem interessante assim do meu ponto de vista.

A subjetividade de cada estudante, com suas experiências anteriores, influencia na relação que ele estabelece com a atividade de escrita da carta. Enquanto o aluno A8, por gostar de escrever, se identificou com a atividade, outros gostam de filosofia (alunos A4 e A9) ou de história (aluno A10), e, para eles, a possibilidade de se comunicar com um cientista do passado, ou ainda, problematizar/refletir sobre o futuro, tornou a atividade atrativa e com significado.

Alguns alunos (A6 e A14, por exemplo) sentiram dificuldade na escrita, não viram sentido na atividade e nem contribuições na sua aprendizagem. A ausência de um interlocutor real, para além do professor, pode ter, nestes casos, influenciado nesta perspectiva, como fica visível na voz de A6:

A6: [...] Se o cara fosse um escritor, tivesse vivo, a gente fosse escrever pra entregar de repente a carta, daí eu acho que teria uma empolgação, teria um maior interesse, mas nesse caso não.

A principal dificuldade destacada pelo professor para usar a leitura e a escrita de textos em sala de aula foi a falta de tempo, tanto para a preparação da atividade - seleção e elaboração do material que será utilizado -, quanto para a aplicação em sala de aula.

Professor: Pontos negativos, que às vezes eu posso usar essa desculpa também, é a questão do tempo. É o tempo em sala de aula e o tempo de preparação da atividade. Porque não é só chegar assim: "Ah, eu gostei". Lê a primeira frase de uma notícia e passar pros alunos. Não. Você tem que ler. Você tem que interpretar. E às vezes eu uso isso também de falar: "Ah, eu estou sem tempo de fazer coisa diferente pros alunos". Mas daí chega em casa fica lá, assistindo televisão, ou aqui na escola fica a maior parte do tempo conversando, em vez de aproveitar realmente pro que interessa. [...] Então um ponto negativo é isso, que não é nem um ponto negativo, é porque nós como professores acabamos dando a desculpa mesmo de falta de tempo.

Primeiramente o professor afirmou que a falta de tempo é uma dificuldade, mas depois disse, em tom de autocrítica, que poderia ser uma desculpa. É preciso considerar que o professor estava se expressando no contexto de uma entrevista e que isso pode ter influenciado a forma como ele expôs seu modo de pensar.

Assim, a inserção da escrita deste gênero neste contexto contribuiu para os estudantes imaginarem novas possibilidades, problematizarem/refletirem sobre o futuro, expressarem sua compreensão e como uma nova forma de operar com o conhecimento 
(dentro da ZDP). As dificuldades mencionadas foram falta de interesse e dificuldade para com a escrita relacionada a conceitos físicos, ausência de um interlocutor real (para além do professor), cultura escolar e condições para preparar e aplicar a atividade (tempo).

\section{Etapa C: Cultura Escolar e da Escola na relação do professor e dos alunos com as práticas de leitura e escrita nas aulas de Física}

A partir de Bakhtin e Vigotski, entende-se que a vivência em um espaço de formação faz com que os sujeitos tenham certa percepção sobre o mundo, e, portanto, também sobre a escola e suas práticas. Nas falas dos sujeitos nas entrevistas, existe uma ressonância dialógica das suas experiências pessoais, dentro e fora do ambiente escolar. Sendo assim, a cultura escolar também influencia na percepção desses indivíduos sobre as práticas inseridas neste espaço. Isso já foi ressaltado em enunciados dos alunos sobre as atividades apresentadas anteriormente, e aqui se reforça a argumentação sobre esse aspecto com outros elementos identificados nas análises.

Pelos dados da investigação, foi possível evidenciar que existe a concepção de que trabalhar a leitura e a escrita é tarefa exclusiva do professor de Língua Portuguesa. Esta era, por exemplo, a concepção do professor com relação à leitura de textos até participar de um momento de formação sobre a temática:

Professor: Eu por um tempo tinha isso. Eu tinha que, não a produção de texto, mas a leitura pra mim a responsabilidade era do professor de português. Aí fiz um workshop de leitura este ano que me mudou completamente o pensamento. [...] A leitura das questões de física, dos textos de física, tem que ser feito pelo professor de física [...].

O professor possuía uma concepção advinda de suas experiências enquanto estudante de Física, nos Ensino Médio e Superior. Ele ressaltou que "não a produção de textos, mas a leitura" era, em sua visão, responsabilidade do professor de Português. O contato com outro discurso, num momento de formação em um workshop e através de sua participação nesta investigação, o levou a uma mudança de percepção sobre a leitura na disciplina: "a leitura das questões de Física, dos textos de Física, tem que ser feito pelo professor de Física".

Ele ainda comentou que muitos alunos tinham resistência para aceitar mudanças nas aulas tradicionais, pois já estavam condicionados a um determinado tipo de aula - e a leitura e escrita de textos pode não fazer parte deste "modelo de aula" instituído como pertinente na disciplina Física.

Professor: [...] falando também de metodologia, tem muito aluno que é muito tradicional, e precisa que o professor escreva no quadro. Acha que leitura é na aula de português.

Esta concepção foi trazida por alguns alunos nas entrevistas, tal como A14:

Entrevistadora: Se você fosse um professor de Física, você usaria a leitura e a escrita de textos para ensinar? 
A14: Eu acho que não, porque isso já tem outro professor que faz daí, eu acho importante isso da leitura e coisa, até porque eu gosto de ler, mas eu acho que não, acho que na minha aula eu deixaria isso pra outro professor.

No enunciado acima, o aluno enfatizou que achava importante e gostava de ler, mas não utilizaria esta prática se fosse professor de Física, "deixaria isso pra outro professor", "porque isso já tem outro professor que faz". Interpreta-se deste enunciado que, para A14, a leitura e a escrita de textos não é uma prática que pertence às aulas de Física, ou seja, como indicou o professor, "tem muito aluno [...] que acha que a leitura é na aula de português". Analisando o contexto extraverbal de A14, ressalta-se que ele tem interesse em continuar estudando na área de exatas, preferindo "cálculos" nas aulas de Física.

Percebe-se assim que, a partir de suas experiências na cultura da escola, os próprios alunos possuem uma concepção do que é ou como deveria ser uma aula de Física, e do que são consideradas atividades escolares pertinentes em cada disciplina.

Pelas entrevistas dos estudantes parece ter havido maior aceitação da atividade de leitura de textos e questões para serem respondidas, em detrimento da escrita da carta para um cientista do passado. Segundo Bakhtin (1992), o domínio de um gênero discursivo requer vivenciar os enunciados em uma determinada esfera de comunicação. Os alunos utilizam certos tipos de enunciados nas aulas de Física - que fazem parte das práticas pertencentes à cultura escolar (Forquin, 1993) - e a inclusão de novos, como a leitura de textos ou a escrita de uma carta, expressando suas próprias relações de sentido, pode gerar dificuldades pela própria inexperiência com esse gênero (Bakhtin, 1992). Ou, ainda, a visão de que este tipo de atividade se enquadra nas práticas de outras disciplinas e não em Física pode ser um obstáculo para atribuir sentidos à mesma.

Em uma análise geral sobre a escrita, percebe-se que os alunos tiveram uma visão positiva sobre a escrita do roteiro experimental (gênero usual nas práticas experimentais, pode ser considerado pertencente à cultura escolar na disciplina em questão), atribuindo maior significado a tal prática para o processo de aprendizagem. O roteiro experimental é um gênero discursivo mais frequente nas aulas da disciplina, também fazendo com que o aluno tenha uma maior propriedade para operar com o conhecimento através dele. Já com relação à escrita da carta, embora alguns alunos a tenham elogiado e se envolvido com a atividade, os resultados indicam que houve uma maior resistência a esta atividade. As aulas de Física possuem um repertório de gêneros do discurso utilizados no processo de ensino-aprendizagem, e talvez a escrita de uma carta não faça parte desse repertório, principalmente pela forma característica de sistematização dos conteúdos na cultura dessa disciplina, através da linguagem matemática. Brait e Pistori (2012) apontam que os gêneros estão sempre ligados a uma tradição, e estão em constante transformação. A escola possui uma determinada tradição nas diferentes disciplinas escolares, ou seja, uma cultura que, muitas vezes, leva professores e alunos a privilegiarem certos tipos de enunciados no contexto de cada disciplina, compondo um repertório usual, que pode ser modificado. Entretanto, a inserção de um gênero diferente nesse espaço pode causar, 
num primeiro contato, certo estranhamento e dificuldade de utilização do mesmo.

\section{Síntese: Leitura e Escrita - Contribuições e dificuldades}

Nos itens anteriores, pela redução e análise dos dados empíricos, foi possível evidenciar contribuições e dificuldades no uso dos diferentes enunciados escritos no contexto investigado.

Na Figura 1, tais contribuições e dificuldades são sintetizadas e sistematizadas:

\begin{tabular}{|c|c|c|c|}
\hline $\begin{array}{l}\text { Modos de } \\
\text { enunciado }\end{array}$ & $\begin{array}{c}\text { Práticas de leitura e } \\
\text { escrita }\end{array}$ & Contribuições & Dificuldades \\
\hline \multirow{4}{*}{$\begin{array}{l}\text { Usuais e já } \\
\text { presentes } \\
\text { no contexto } \\
\text { investigado }\end{array}$} & $\begin{array}{l}\text { Leitura (opcional) em } \\
\text { buscas individuais } \\
\text { prévias às aulas }\end{array}$ & $\begin{array}{l}\text { Buscar mais informações } \\
\text { sobre o conteúdo } \\
\text { Melhor compreender } \\
\text { conteúdos estudados em } \\
\text { sala }\end{array}$ & $\begin{array}{l}\text { Interpretação de textos pelos } \\
\text { alunos } \\
\text { Preferência por obter } \\
\text { informações por áudio e vídeo }\end{array}$ \\
\hline & Escrita na caderneta & $\begin{array}{l}\text { Manter a atenção nas } \\
\text { explicações } \\
\text { Memorizar informações } \\
\text { Estudar/compreender o } \\
\text { conteúdo }\end{array}$ & $\begin{array}{l}\text { Visão limitada da } \\
\text { funcionalidade da escrita } \\
\text { Cultura Escolar (alguns alunos } \\
\text { desejam que o professor } \\
\text { esquematize os conceitos no } \\
\text { quadro para serem copiados no } \\
\text { caderno) } \\
\end{array}$ \\
\hline & $\begin{array}{l}\text { Leitura do } \\
\text { texto base para } \\
\text { desenvolvimento } \\
\text { da atividade } \\
\text { experimental }\end{array}$ & $\begin{array}{l}\text { Compreender os } \\
\text { experimentos }\end{array}$ & $\begin{array}{l}\text { Interpretação de textos pelos } \\
\text { alunos } \\
\text { Preferência por obter } \\
\text { informações por áudio e vídeo }\end{array}$ \\
\hline & $\begin{array}{l}\text { Escrita do roteiro } \\
\text { experimental }\end{array}$ & $\begin{array}{l}\text { Compreender e organizar } \\
\text { ideias } \\
\text { Expressar o conhecimento } \\
\text { Guiar a apresentação } \\
\text { ou explicação oral dos } \\
\text { experimentos } \\
\text { Para o professor, avaliar } \\
\text { o desempenho dos } \\
\text { estudantes na atividade }\end{array}$ & $\begin{array}{l}\text { Visão de que a escrita não é } \\
\text { necessária } \\
\text { Visão limitada sobre a } \\
\text { funcionalidade da escrita } \\
\text { (necessidade de guia com } \\
\text { questões específicas/modelo a } \\
\text { ser seguido) }\end{array}$ \\
\hline
\end{tabular}

Figura 1. Leitura e escrita: Contribuições e dificuldades (continua) 


\begin{tabular}{|c|c|c|c|}
\hline $\begin{array}{r}\text { Modos de } \\
\text { enunciado }\end{array}$ & $\begin{array}{c}\text { Práticas de leitura e } \\
\text { escrita }\end{array}$ & Contribuições & Dificuldades \\
\hline \multirow[t]{2}{*}{$\begin{array}{l}\text { Não usuais } \\
\text { no contexto } \\
\text { investigado }\end{array}$} & $\begin{array}{l}\text { Leitura dos textos } \\
\text { de história do } \\
\text { Eletromagnetismo, } \\
\text { retirados do livro } \\
\text { didático }\end{array}$ & $\begin{array}{l}\text { Complementar } \\
\text { informações e } \\
\text { discussões } \\
\text { Ampliar o olhar e } \\
\text { compreensão sobre os } \\
\text { conceitos (História e } \\
\text { Filosofia da Ciência/ } \\
\text { temática do texto) } \\
\text { Despertar novos } \\
\text { interesses aos alunos, } \\
\text { relacionados com leitura } \\
\text { ou temática do texto }\end{array}$ & $\begin{array}{l}\text { Interpretação de textos pelos } \\
\text { alunos } \\
\text { Falta de concentração dos } \\
\text { alunos } \\
\text { Falta de interesse pela leitura ou } \\
\text { temática do texto } \\
\text { Falta de diálogo/mediação em } \\
\text { sala de aula } \\
\text { Formação do professor } \\
\text { (insegurança pela diversidade do } \\
\text { conteúdo) } \\
\text { Cultura Escolar (alunos } \\
\text { sentem falta de questões mais } \\
\text { específicas, focadas no texto - } \\
\text { busca de informações; a leitura } \\
\text { deve ser trabalhada em outras } \\
\text { disciplinas) } \\
\text { Condições para o professor } \\
\text { preparar e aplicar a atividade }\end{array}$ \\
\hline & $\begin{array}{l}\text { Escrita da carta para } \\
\text { William Gilbert }\end{array}$ & $\begin{array}{l}\text { Imaginar novas } \\
\text { possibilidades } \\
\text { Problematizar/refletir } \\
\text { sobre o futuro } \\
\text { Expressar sua } \\
\text { compreensão } \\
\text { Nova forma de operar } \\
\text { com o conhecimento }\end{array}$ & $\begin{array}{l}\text { Dificuldade e falta de interesse } \\
\text { para com a escrita relacionada a } \\
\text { conceitos físicos } \\
\text { Inexperiência com o gênero } \\
\text { Ausência de interlocutor real, } \\
\text { para além do professor } \\
\text { Cultura Escolar (facilidade } \\
\text { com o roteiro experimental e } \\
\text { dificuldade na escrita "mais } \\
\text { livre" da carta; alguns não } \\
\text { veem significado na atividade } \\
\text { proposta) } \\
\text { Condições para o professor } \\
\text { preparar e aplicar a atividade } \\
\text { (falta de tempo) }\end{array}$ \\
\hline
\end{tabular}

Figura 1. Leitura e escrita: Contribuições e dificuldades (continuação)

Percebe-se que a intervenção da pesquisadora no contexto, propondo um modo não usual de enunciados escritos nas aulas, possibilitou realizar análises à luz do conceito de cultura escolar e da escola (Forquin, 1993), ampliando o conhecimento acerca das contribuições, possibilidades e dificuldades em relação à escrita e leitura de textos nas 
aulas de Física, já publicados na literatura da área.

Buscando identificar a natureza das dificuldades identificadas pelos alunos e pelo professor, foi construída a Figura 2. As colunas apresentam dificuldades relacionadas aos estudantes e dificuldades relacionadas a outros aspectos, uma vez que estudos têm apontado que há uma tendência de se atribuir aos estudantes o não sucesso deste tipo de atividade (Amaral, 2010; Andrade, \& Martins, 2006). Nesta investigação, foi possível identificar também outros aspectos gerais que dificultam a adoção dessas práticas.

\begin{tabular}{|l|l|l|}
\hline \multirow{2}{*}{ Práticas } & \multicolumn{2}{|c|}{ Natureza das dificuldades } \\
\cline { 2 - 3 } Leitura & \multicolumn{1}{|c|}{ Relacionadas aos Estudantes } & \multicolumn{1}{c|}{ Relacionadas a outros aspectos } \\
\hline \multirow{5}{*}{ Escrita } & $\begin{array}{l}\text { Interpretação de textos } \\
\text { Desinteresse pela temática do texto } \\
\text { Preferência por outras formas de acesso } \\
\text { ao mesmo conteúdo (vídeo e áudio) } \\
\text { Desinteresse pela leitura }\end{array}$ & $\begin{array}{l}\text { Cultura escolar e da escola (falta de } \\
\text { familiaridade com práticas diferenciadas } \\
\text { e outros gêneros do discurso na disciplina } \\
\text { Física) } \\
\text { Formação do professor (insegurança } \\
\text { pela diversidade do conteúdo, que pode } \\
\text { influenciar a falta de discussão/diálogo em } \\
\text { sala de aula) } \\
\text { Precárias condições de trabalho docente para } \\
\text { preparar a atividade (falta de tempo) }\end{array}$ \\
\hline & $\begin{array}{l}\text { Estruturação de textos } \\
\text { escriteresse e desmotivação com a }\end{array}$ & \\
\hline
\end{tabular}

Figura 2. Leitura e escrita: A natureza das dificuldades.

O tempo escasso para planejar (precárias condições de trabalho) e desenvolver atividades de leitura e escrita é citado pelo professor na entrevista como a principal dificuldade e acaba influenciando na forma de desenvolvimento de todas as atividades discutidas na Figura 1.

Isso por um lado evidencia elementos importantes a serem considerados se se deseja alguma mudança nas práticas de ensino: as precárias condições de trabalho dos professores da Educação Básica (que dificultam planejamentos de atividades ainda não usuais). Por outro lado, ao se considerar que, diante destas dificuldades, em geral os professores optam por continuar a desenvolver majoritariamente atividades já tradicionalmente incorporadas e consideradas importantes na cultura escolar nesta disciplina, isso também evidencia o quanto a cultura escolar já estabelecida é importante na seleção dos modos de ensinar (e consequentemente, sugerindo aos alunos os modos valorizados do aprender na disciplina).

A Figura 2 evidencia que as dificuldades relacionadas/atribuídas aos estudantes podem ser decorrentes do não uso e incentivo dessas práticas no contexto da disciplina. Assim, elementos que muitas vezes são sugeridos como dificuldades, poderiam ser tomados como uma indicação da necessidade de se adotar esse tipo de atividade na aprendizagem de Física de forma mais sistemática, uma vez que Vigotski (2008) e Bakhtin (1992) ressaltam a importância da experiência para a aprendizagem de conceitos e domínio de diferentes formas de enunciados. 


\section{Conclusões e Implicações}

Esta investigação teve como objetivo analisar as perspectivas dos diferentes sujeitos - professor e estudantes de um contexto escolar -, sobre as contribuições e dificuldades de práticas de leitura e escrita em aulas de Física, com reflexões à luz dos conceitos de cultura escolar e da escola (Forquin, 1993).

As análises dos dados empíricos da investigação mostram que o envolvimento dos alunos e os sentidos atribuídos às atividades têm relação com suas características culturais (Forquin, 1993), isto é, de seu perfil e interesse pela leitura ou escrita, ou ainda pela temática da atividade. As contribuições das atividades desenvolvidas durante a investigação, por exemplo, não são positivas para todos os estudantes; existem nuances, individualidades, expressas nas vozes dos sujeitos entrevistados (Bakhtin, 1992). A partir dos resultados sintetizados das Figuras 1 e 2, pode-se refletir sobre algumas relações que ganham destaque.

Nos modos já usuais de utilização de leitura e escrita no contexto investigado, a leitura (seja em buscas individuais ou para o desenvolvimento da atividade experimental) contribuiu favorecendo uma melhor compreensão do conhecimento, ao mesmo tempo em que resultou em dificuldades de interpretação de textos pelos estudantes.

Nas vozes dos sujeitos participantes parece que, de forma geral, os textos, por serem escritos, possuem limitações quanto à sua potencialidade para a aprendizagem do estudante, isto é, os textos auxiliam na aprendizagem de Física quando associados a outro tipo de contato do estudante com o conhecimento (áudio, vídeo ou diálogo com o professor). Quando existe um contexto de significação maior, parece que se torna possível ao estudante estabelecer sentidos para o texto escrito.

Por sua vez, a escrita na caderneta é vista como positiva pelos estudantes em relação à memorização dos conhecimentos. Em relação ao roteiro experimental (não obrigatório) também parece haver uma visão positiva, associada à Cultura Escolar (como um passo a passo de atividades - dever escolar - e como um instrumento para o professor avaliar).

As práticas deleitura e escrita alternativas, propostas no contexto desta investigação - a leitura de textos do livro didático envolvendo elementos históricos e a escrita da carta -, trouxeram novos aspectos sobre os conhecimentos de Eletromagnetismo que estavam sendo estudados no bimestre em questão. A atividade foi significativa dentro de um contexto maior de aprendizagem sobre aquele conhecimento; em meio aos exercícios, problemas, roteiros e relatórios experimentais foi possível desenvolver novas formas de trabalhar o ler e o escrever que permitiram outras possibilidades para refletir e construir conhecimentos em Física. Entretanto, tanto na leitura quanto na escrita, se comparadas às contribuições, as dificuldades foram mencionadas em maior número (Figura 1).

A Figura 2, específica sobre as dificuldades, mostra que algumas estão relacionadas (ou são atribuídas) aos estudantes, pelas dificuldades de vocabulário, interpretação e estruturação de textos. Isso já vem sendo apontado por diversos estudos da literatura (Almeida, Silva, \& Babichak, 1999; Amaral, 2010; Andrade, \& Martins, 
2006). Compreendendo que a interpretação e a escrita não são dons naturais (Vigotski, 2008), mas precisam ser desenvolvidas também por meio da educação formal, as dificuldades relacionadas com (ou atribuídas a) os estudantes podem ser decorrentes do não incentivo do uso dessas práticas nas aulas ou ainda da forma como são utilizadas.

Este estudo avança ao apontar ainda dificuldades relacionadas a outros aspectos (para além dos estudantes), com destaque para a formação do professor e a Cultura Escolar (Figura 2). A voz do professor participante desta investigação possui ressonâncias dialógicas de momentos de formação que parecem ter sidos significativos em seu olhar acerca deste tipo de atividade, todavia ele ainda aponta uma dificuldade de formação dos professores em geral relacionada aos conhecimentos específicos das disciplinas (dominar os diferentes aspectos sobre os conhecimentos para propor atividades que geram questionamentos por parte dos estudantes).

Em relação à Cultura Escolar, a partir de estudos da literatura que focam em questões e atividades mais específicas envolvendo a leitura (Almeida, Silva, \& Machado, 2001; Assis, \& Teixeira, 2005; Pagliarini, \& Almeida, 2014; Silva, 2013) ou escrita (Charret, \& Krapas, 2008; Paula, \& Talim, 2015), e de outros que apontam dificuldades de professores com este tipo de atividade (Andrade, \& Martins, 2006; Assis, \& Carvalho, 2008) buscou-se inserir atividades envolvendo o ler e escrever, no contexto de um bimestre de atividades, integradas à forma usual de trabalho de um professor, a partir das Etapas A e B. Por este caminho, foi possível se construir as reflexões sobre a Cultura Escolar na Etapa $\mathrm{C}$ deste estudo. Estas perspectiva e análise permitiram ampliar os resultados já registrados na literatura da área, ao enfatizar a influência da Cultura Escolar no desenvolvimento desse tipo de atividade, no sentido de poder moldar as perspectivas dos professores e alunos sobre as práticas escolares na disciplina Física.

Este estudo foi desenvolvido em uma turma do último bimestre do terceiro ano do Ensino Médio, contexto no qual a influência da cultura escolar pode ficar ainda mais expressiva. A cultura escolar específica do terceiro ano do Ensino Médio (contexto extraverbal), afetada também pela proximidade de avaliações tais como o Exame Nacional do Ensino Médio (ENEM) e/ou vestibulares - embora não tenham sido explicitamente mencionados nas vozes do professor ou dos estudantes entrevistados pode ter influenciado os resultados deste estudo. Isto porque há práticas tradicionais reconhecidas como importantes na aprendizagem de tal disciplina, também valorizadas nestas avaliações externas à sala de aula e com significativo impacto na vida de alguns estudantes.

Desta forma, práticas tais como leitura e escrita de textos, ressaltando outros aspectos sobre os conhecimentos, podem significar dificuldades nas perspectivas dos sujeitos, o que pode diminuir a potencialidade das mesmas para favorecer a aprendizagem. Assim, a adoção da leitura e da escrita como um meio pedagógico significativo para ensinar e aprender Física na escola requer, além de pensar o contexto de ensino-aprendizagem e em como integrá-las de forma orgânica à disciplina, ter em conta que se está lidando com uma questão de cultura escolar e da escola. 


\section{Financiamentos}

O presente trabalho foi realizado com apoio da Coordenação de Aperfeiçoamento de Pessoal de Nível Superior - Brasil (CAPES) - Código de Financiamento 001.

\section{Referências}

Andrade, I. B., \& Martins, I. (2006). Discursos de professores de ciências sobre leitura. Investigações em Ensino de Ciências, 11(2), 121-151. Recuperado de https://www. if.ufrgs.br/cref/ojs/index.php/ienci/article/view/491/293

Almeida, M. J. P. M., \& Mozena, E. R. (2000). Luz e Outras Formas de Radiação Eletromagnética: Leituras na $8^{\text {a }}$ Série do Ensino Fundamental. Revista Brasileira de Ensino de Física, 22(3), 426-433. Recuperado de http://www.cepa.if.usp.br/e-fisica/ apoio/textos/v22_426.pdf

Almeida, M. J. P. M., Silva, H. C., \& Babichak, C. C. (1999). O movimento, a mecânica e a Física no Ensino Médio. Revista Brasileira de Ensino de Física, 21(1), 195-201. Recuperado de http://efisica.if.usp.br/apoio/artigosapoio/v21_195.pdf

Almeida, M. J. P. M., Silva, H. C., \& Machado, J. L. M. (2001). Condições de produção no funcionamento da leitura na educação em física. Revista Brasileira de Pesquisa em Educação em Ciências, 1(1). Recuperado de https://periodicos.ufmg.br/index.php/ rbpec/article/view/4180

Almeida, M. J. P. M., \& Ricon, A. E. (1993). Divulgação Científica e texto literário - uma perspectiva cultural em aulas de Física. Caderno Catarinense de Ensino de Física, 10(1), 7-13. http://dx.doi.org/10.5007/\%25x

Amaral, E. T. (2010). O professor de ensino médio e o seu olhar sobre a leitura e a escrita em sua disciplina. (Dissertação de Mestrado). Programa de Pós-Graduação em Educação, UNIMEP, Piracicaba.

Assis, A., \& Carvalho, F. L. C. (2008). A postura do professor em atividades envolvendo a leitura de textos paradidáticos. Revista Brasileira de Pesquisa em Educação em Ciências, 8(3). Recuperado de https://periodicos.ufmg.br/index.php/rbpec/article/view/4014

Assis, A., \& Teixeira, O. P. B. (2005). Uma avaliação dos alunos sobre o uso de um texto paradidático no ensino de física. In Atas V Encontro Nacional de Pesquisas em Educação em Ciências. Bauru, SP/Brasil.

Bakhtin, M. (1992). Os gêneros do discurso. In M. Bakhtin. Estética da criação verbal (pp. 277-326). São Paulo, SP/Brasil: Martins Fontes.

Bubnova, T. (2011). Voz, sentido e diálogo em Bakhtin / Voice, sense and dialogue on Bakhtin (R. L. Baronas, \& F. Tonelli, Trad). Bakhtiniana, 6(1), 268-280. (Obra original publicada em 2006). http://dx.doi.org/10.1590/S2176-45732011000200016 
Brait, B., \& Pistori, M. H. C. (2012). A produtividade do conceito de gênero em Bakhtin e o círculo. Alfa, 56(2), 371-401. Recuperado de http://seer.fclar.unesp.br/alfa/article/ viewFile/5531/4343

Carvalho, J. A. B., \& Barbeiro, L. F. (2013). Reproduzir ou construir conhecimento? Funções da escrita no contexto escolar português. Revista Brasileira de Educação, 18(54), 609-628. Recuperado de http://www.scielo.br/pdf/rbedu/v18n54/06.pdf

Carvalho, R. G. G. (2006). Cultura global e contextos locais: a escola como instituição possuidora de cultura própria. Revista Iberoamericana de Educación, 39(2), 1-9. Recuperado de https://rieoei.org/deloslectores/1434GilGomes.pdf

Castro, G. (2014). Discurso citado e memória: ensaio bakhtiniano sobre Infância, e São Bernardo. Chapecó: Argos.

Castro, G. (2010). Bakhtin e a Análise do Discurso. In L. Paula de, \& G. Stafuzza. Da análise do Discurso no Brasil à Análise do Discurso do Brasil: três épocas históricoanalíticas (pp. 89-118). Uberlândia, MG/Brasil: EDUFU.

Charret, H. C., \& Krapas, S. (2008). O discurso da física escolar como uma linguagem social particular: um olhar sobre a redação dos alunos. In Atas XI Encontro de Pesquisa em Ensino de Física. Curitiba, PR/Brasil.

Chaves, T. V., Mezzomo, J., \& Terrazan, E. A. (2001). Avaliando práticas didáticas de utilização de textos de divulgação científica como recurso didático em aulas de física no ensino médio. In Atas III Encontro Nacional de Pesquisas em Educação em Ciências. Atibaia, SP/ Brasil.

Chervel, A. (1990). História das disciplinas escolares: reflexões sobre um campo de pesquisa (G. L. Louro, Trad.). Teoria \& Educação, 2, 177-229. (Obra original publicada em 1988). Recuperado de https://moodle.fct.unl.pt/pluginfile.php/122510/mod_ resource/content/0/Leituras/Chervel01.pdf.

Cruvinel, F. R. (2010) Ensinar a ler na escola: a leitura como prática cultural. Ensino EmRevista, 17(1), 249-276. Recuperado de http://www.seer.ufu.br/index.php/emrevista/ article/view/8194/5212

Ferreira, J. C. D., \& Raboni, P. C. A. (2013). A ficção científica de Júlio Verne e o ensino de Física: uma análise de "Vinte mil léguas submarinas". Caderno Catarinense de Ensino de Física, 30(1), 84-103. https://doi.org/10.5007/2175-7941.2013v30n1p84

Flôr, C. C., \& Cassiani, S. (2011). O que dizem os estudos da linguagem na educação científica. Revista Brasileira de Pesquisa em Educação em Ciências, 11(2), 67-86. Recuperado de https://periodicos.ufmg.br/index.php/rbpec/article/view/4197

Forquin, J. (1993). Escola e Cultura: As bases sociais e epistemológicas do conhecimento escolar (G. L. Louro, Trad.). Porto Alegre: Artes Médicas (Obra original publicada em 1989). 
Gaspar, A. (2014). Atividades experimentais no ensino de Física: uma nova visão baseada na teoria de Vigotski. São Paulo: Editora Livraria da Física.

Góes, M. C. R. (2001). A construção de conhecimentos e o conceito de zona de desenvolvimento proximal. In E. F. Mortimer, \& A. L. B. Smolka. Linguagem, Cultura e Cognição: reflexões para o ensino e a sala de aula (pp. 77-88). Belo Horizonte, MG/ Brasil: Autêntica.

Guedes, P. C., \& Souza, J. M. (2011). Leitura e escrita são tarefas da escola e não só do professor de português. In I. C. B. Neves, N. O. Schaffer. Ler e escrever: compromisso de todas as áreas. 9 ed. Porto Alegre, RS/Brasil: Editora da UFRGS.

Hedegaard, M. (1996). A zona de desenvolvimento proximal como base para a instrução. In L. C. Moll. Vygotsky e a educação: implicações pedagógicas da psicologia sóciohistórica. Porto Alegre, RS/Brasil: Artes Médicas.

Jobim e Souza, S. (2008). Infância e Linguagem: Bakhtin, Vygotsky e Benjamin. Campinas: Papirus.

Lessard-Hébert, M., Goyette, G., \& Boutin, G. (1990). Investigação qualitativa: fundamentos e práticas. Lisboa: Instituto Piaget.

MEC. (2013). Diretrizes Curriculares Nacionais da Educação Básica. Brasília: Secretaria da Educação Básica.

Mendes-Filho, L. F., Gonçalves, I. A., Vidal, D. G., \& Paulilo, A. L. (2004). A cultura escolar como categoria de análise e como campo de investigação na história da educação brasileira. Educação e Pesquisa, 30(1), 139-159. Recuperado de www.scielo.br/pdf/ep/ v30n1/a08v30n1.pdf

Pagliarini, C. R., \& Almeida, M. J. (2014). Física Quântica numa Leitura de Divulgação Científica no início do Ensino Médio: manifestações dos estudantes. In Simpósio sobre Divulgação Científica na sala de aula: perspectivas e possibilidades. São Paulo, SP/Brasil: USP.

Paula, H. F., \& Talim, S. L. (2015). Avaliação de estudantes sobre a prática de produzir registros das atividades de ciências. Revista Ensaio,17(1), 14-38. http://dx.doi. org/10.1590/1983-211720175170101

Setlik, J., \& Higa, I. (2017). Writing in Physics classes in High School: possibilities. In M. Pietrocola, I. Gurgel, C. Leite, (Org.), Contemporary science education and challenges in the presente society: perspectives in physics teaching and learning (pp. 96-99). São Paulo, SP/Brasil: FEUSP.

Silva, A. C. (2013). Leitura sobre ressonância magnética nuclear em aulas de física do ensino médio. (Dissertação de Mestrado). Faculdade de Educação, Universidade Estadual de Campinas, Campinas. 
Silva, H. C. (1997). Como, quando e o que se lê em aulas de física no ensino médio: elementos para uma proposta de mudança. (Dissertação de Mestrado). Faculdade de Educação, Universidade Estadual de Campinas, Campinas.

Veneu, A., Ferraz, G., \& Rezende, F. (2015). Análise de discursos no ensino de ciências: considerações teóricas, implicações epistemológicas e metodológicas. Ensaio Pesquisa em Educação em Ciências, 17 (1), 126-149. http://dx.doi.org/10.1590/1983211720175170106

Vigotski, L. S. (2008). Pensamento e linguagem. 4. ed. São Paulo: Martins Fontes.

Vigotski, L. S. (2014). Aprendizagem e desenvolvimento intelectual na idade escolar. In L. S. Vigotski, A. R. Luria, A. N. Leontiev. Linguagem, desenvolvimento e aprendizagem (pp. 103-117). 13. ed. São Paulo, SP/Brasil: Ícone.

\section{Joselaine Setlik}

${ }^{0}$ https://orcid.org/0000-0003-3242-2550 Universidade Federal de Santa Catarina Programa de Pós-Graduação em Educação Científica e Tecnológica Florianópolis, Santa Catarina, Brasil joselaine.setlik@posgrad.ufsc.br

Ivanilda Higa

https://orcid.org/0000-0002-7277-3198 Universidade Federal do Paraná Setor de Educação, Departamento de Teoria e Prática de Ensino Programa de Pós-Graduação em Educação Curitiba, Paraná, Brasil ivanilda@ufpr.br

Submetido em 04 de novembro de 2018 Aceito em 19 de agosto de 2019 Publicado em 13 de outubro de 2019 